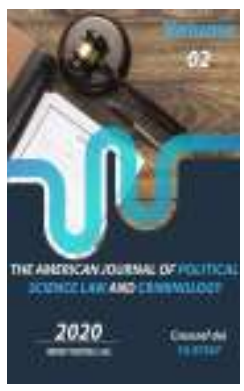

\title{
Prevention Of Offenses Among Minors
}

\author{
Mukaddaskhon Tursunovna Akhmedova \\ Doctor In Law (DSc), Assistant Professor At The Department Of "Sectoral Legal Sciences" of \\ Military-Technical Institute Of The National Guard Of The Republic Of Uzbekistan
}

Journal Website: http://usajournalshub.c om/index,php/tajpslc

Copyright: Original content from this work may be used under the terms of the creative commons attributes 4.o licence.

\section{ABSTRACT}

This article is devoted to the prevention of offenses and crimes and also strengthening the legal framework for the protection of the right and interests of minors, prevention of neglect and juvenile delinquency, highlights the ongoing large-scale reforms.

\section{KEYWORDS}

Juvenile, offence, crime, younger generation, prevention, law and interests, control, education.

\section{INTRODUCTION}

One of the strata of the population that is at the center of our state and society are minors, and caring for them is a priority among our social mission. As we care about the younger generation, we focus on the fact that they are our backbone and the successors of our future. Today, one of the vital tasks for our independent Republic is to bring up the younger generation as a comprehensively mature person. Particular attention is paid to the maturity of the younger generation, who will be the owners of tomorrow, their education at the level of modern requirements. As the President of the Republic of Uzbekistan Sh. Mirziyoyev noted: "...nowadays the education of young people remains for us an issue that will never lose its relevance and importance" [1]. 


\section{METHODS}

In recent years, the bodies and institutions responsible for the harmonious development of juveniles in our country, the prevention of delinquency and crime, the strengthening of the legal framework for the protection of the rights and interests of minors, the prevention of juvenile delinquency attention is being paid. In particular, professors and cadets of the Military-Technical Institute of the National Guard of the Republic of Uzbekistan today are actively involved in many activities aimed at early prevention of delinquency and crime. Therefore, since February of this year, they have been regularly involved in maintaining public order in the Ferghana Valley and Almazar district of Tashkent. In particular, we, the cadets of the Institute, are learning to consider appeals from different segments of the population and provide them with legal advice in the "Legal Clinics" operating in the region. This creates a wide range of opportunities to apply our theoretical knowledge in practice.

\section{RESULTS AND DISCUSSIONS}

In this regard, the following should be mentioned about the minor: According to the Law of the Republic of Uzbekistan "On guarantees of the rights of the child", the terms "minor" and "child" mean persons under 18 years of age. From a criminal point of view, juveniles are considered to have reached the age of thirteen before the commission of the crime, but not under the age of eighteen. Juveniles are not yet fully developed physically and mentally, and require special care in terms of physiological characteristics, responsibility and punishment, legal protection and a humane approach. The division of the responsibility of minors into a separate independent section means that the rules of criminal liability against them should be applied taking into account the special rules specified in this section. The introduction of such rules in the Criminal Code is conditioned by the sociopsychological characteristics of this age group. Individuals between the ages of fourteen and eighteen, on the one hand, achieve a certain level of socialization (they develop feelings of independence, self-control, self-control), on the other hand - the subsequent socialization of the individual (degree of social adaptation, in society self-seeking, increasing life experience, lack of moral skills, and limited ability to anticipate the consequences of their actions, etc.). Individuals of this age are characterized by indecision, irritability, inability to properly assess the situation in the face of insecurity, and so on. No human being is born a criminal from his mother, and his relatives, as well as his "friends" in quotes, unknowingly commit dangerous acts. It is true that there are those among us who do not obey the laws of Uzbekistan, do not get rid of the whirlpool of crime and never think of anything but themselves the thousands of our fellow citizens who promise are worth forgiving, giving them another chance, of course. This year has been an unforgettable one in the lives of our compatriots. The head of our state has pursued a policy of forgiveness of true human nature. On the one hand, this is significant for the first time in the history of Uzbekistan, and on the other hand, the families of many of our compatriots are full of joy. One was returned to his father, another to his mother, and still another to his relatives. At the same time, it testifies to the fact that each of our compatriots and his family members is always in the eyes of our President and how noble he is. Among the large-scale reforms being carried out in the country, special attention is paid to minors. Therefore, one of the important tasks is to ensure the well-being of our future and to bring up our youth as well-rounded people. This in itself requires the younger generation to 
be well-educated, physically healthy, with high intellectual potential.

It is important to inculcate in the minds of the younger generation the important criterion of the rule of law, that is, the rule of law. The wisdom of our people "knowledge is like a pattern carved on a stone from youth" has not lost its significance to this day. Today in our country, sufficient conditions, organizational, legal and institutional mechanisms are created for the legal education of minors. In our country, serious attention is paid to the issues of harmonious upbringing of the younger generation at the level of state policy. In particular, the Law of the Republic of Uzbekistan "On the prevention of juvenile delinquency and delinquency" adopted on September 29, 2010 [2] provides mechanisms for the prevention of juvenile delinquency and delinquency. Because, if we look at the policy of the great Sahibkiran on such an issue, in the state of Amir Temur, one of the main rules of Islamic law, and now the internationally accepted rule, that is, the "personality of the crime" was strictly observed. More precisely, his relatives, brothers, were not held accountable for the guilt of the offender if they did not participate in the crime. Also, the person who committed the crime was not left unpunished and the innocent person was not allowed to be punished. Amir Temur considered this procedure as one of the main rules of the state legal system. "I have judged both the guilty and the innocent with compassion and justice. I took the right of the oppressed from the oppressor. I did not oppress him instead of the oppressor. The work being done in our country to strengthen the rights and legitimate interests of minors, strengthening the responsibility of state and public associations in the implementation of state youth policy is an important factor in educating a healthy spiritually mature generation. In the upbringing of young people, the phrase of the thinker Abdulla Avloni "Education is for us a matter of life or death, salvation or destruction, happiness or disaster" has become a working principle of the family, neighborhood and school. Therefore, not only government agencies, but also nongovernmental organizations, public associations, religious organizations, especially citizens' self-government bodies, as well as educational institutions and parents should take responsibility for the upbringing of young people in a spiritually pure, mentally healthy and physically strong way and active efforts should be made in this regard. When it comes to the importance of the family in the upbringing of children, we must not forget that parents and grandparents also have an invaluable contribution. Therefore, one of our great scholars, Mahmud Zamakhshari, said: "Your fame and honor come from your father. Hypocrisy comes from your mother". Abdullah Gijduvani said, "Always do the right of the parents". In addition, the following opinion of Ghafur Ghulam gives us a deeper understanding of the truth: "The Uzbek people can be proud not only of their brave, courageous fathers, but also of their mothers, who are brave, fearless and able to stand up to adversity" [3].

\section{CONCLUSION}

- In order to increase the effectiveness of legal education of young people and the development of legal education in accordance with modern requirements, special attention should be paid to the following aspects:

- Taking into account the specifics of young people's understanding of legal norms in the implementation of legal education;

- Encourage minors to understand the social significance and moral value of legal norms and to assume the rights and duties established by law; 
- Take into account that the effectiveness of legal education depends in many respects on the degree to which it adheres to the requirements of ethical norms;

- Comprehensive development of legal activity of young people, fostering intolerance of any manifestations of law and order violations;

- Preparation of a new generation of legal literature for preschools, secondary and secondary special, higher education institutions;

- Collaborate with governmental and nongovernmental organizations dealing with juvenile affairs on the formation of legal awareness and culture of young people;

- To develop students' ability to independently apply legal knowledge acquired in practice, in assessing the behavior of themselves and others;

- Formulation of guidelines for the implementation of only legal actions in accordance with the law and other regulations;

- Fostering the virtue of being firm in dealing with any offense. In short, the legal education of minors should be based on the concept of "family-neighborhoodschool", the adequate knowledge of the law and the principles of humanity embodied in it, the legal norms in society, law and order in society, the importance of legal rules. It is expedient to take measures to increase the participation of young people in law enforcement activities, to inculcate in the minds of young people the skills of acceptance and ownership. to the development of the country and the well-being of the people // Khalk suzi. December 8, 2016, № 243 (6678).

2. www/lex/uz/

3. Wise thoughts of fellow scholars. Tashkent: Yangi asr avlodi, 2012. -p. 84-85.

\section{REFERENCES}

1. Sh.Mirziyoyev. The rule of law and the protection of human interests are the key 